\title{
Power and Control in Knowledge-Intensive Firms: Post-Bureaucratic Firms and Enterprise Culture
}

\author{
Samuel Osei-Nimo, Imani Silver Kyaruzi \\ QAHE/Ulster University, Birmingham/London, UK \\ Email: samuel.osei-nimo@qa.ulster.ac.uk, Imani.kyaruzi@qa.ulster.ac.uk
}

Received 9 October 2015; accepted 24 October 2015; published 29 October 2015

Copyright (C) 2015 by authors and OALib.

This work is licensed under the Creative Commons Attribution International License (CC BY). http://creativecommons.org/licenses/by/4.0/

(c) (i) Open Access

\section{Abstract}

This paper discusses the notions of "entrepreneurialism" and enterprising culture. In particular, it examines the significance of such discourses on the contemporary workplace and consequent impact on the individual worker's identity and behaviour. Previous studies on Knowledge-Intensive Firms suggest that organisations are not entirely synonymous with post bureaucratic organisations, but mainly overlap it. It is revealed that majority of firms rely on "cultural or professional forms of control". These forms of control are regarded to have dependence on an ideology of entrepreneurialism and enterprising culture. Thus, the issues of power relations and discourses in Knowledge-Intensive firms are primarily investigated in this study to expose and understand how the drive by organisations for the "enterprising" individual produces a worker who is self-regulating and self-disciplined. The paper includes an assessment of discourses from various organisational actors to shed light on the roles played by "an enterprise" as a principle of control or government in creating autonomous and productive subjects in the workplace and wider society.

\section{Keywords}

Post-Bureaucratic Firms, Entrepreneurial Culture, Post-Structuralism, Power-Relations, Discourses

Subject Areas: Organizational Behavior

\section{Introduction}

Modern organisations in the western societies over the years have acted as vital part of the organisational actors' lives as they play a significant role in shaping their identities through various organisational discourses and practices. The purpose of this paper, is therefore, to show that although the wider societal practices and perceptions may affect an individual's societal attitudes, particularly in the workplace, there is also a significant role 
that contemporary organisations play in the production of certain organisational identities-these roles are linked to the discourses and entrepreneurial behaviour practices and the notion of the enterprising culture emerging in Western societies.

The paper is divided into three main sections. First, we discuss some of the theoretical and conceptual parts of the most important themes of this study: construction of the contemporary organisations in modern societies. In the second part, an overview of the entrepreneurial culture and post-bureaucratic organisations that have emerged in the United Kingdom and other Western countries will be discussed. The discussions are centred on the emergence of the "anti-bureaucratic" thinking that mainly involves an understanding that bureaucratic organizations are viewed as not being capable of accommodating probing, creative, and entrepreneurial individuals. The evaluation seeks to expose and highlight the facts on how contemporary organisations have moved from rigidly devised system of rules, standard operating procedures, and clearly distinguished domains of expertise and authority [1], to newer forms of control. The third section will address the issues of power relations and how the move from the bureaucratic to a post-bureaucratic workplace has rendered the individual into an "enterprising-self"- - that is, a calculating self, who is calculative about itself and works upon itself in order to better itself (Rose, 1990). Finally, we provide some discussion regarding the usefulness of the main themes of this study. Above all, we address the relevance of understanding the nuances involved in discourses pertaining an "enterprise-culture" and the power that they have in moulding and shaping the lives of organisational actors, particularly in knowledge-intensive firms. More importantly, this paper draws on Michel Foucault's work on power relations - interactions between power relations and discourses (expert and lay knowledge) to understand why/ how certain organisational discourses and practices become dominant over time; that is, why/how the entrepreneurialism has become a key concept in the workplace.

\section{The Construction of "Contemporary" Organisations in Western Societies}

According to Watson [2], work organisations are important to the way in which modern industrialised civilisations are ordered. Thus at the heart of the history of contemporary societies have emerged organisational activities which are often undertaken inside "bureaucratised corporations and formally structured enterprises that employ people to work under the instructions of organisational managers” ([2], p. 75).

Strati [3] in explaining the relevance of organisations to modern societies refers to them as the centre of gravity of contemporary societies. Based on the aims of this paper, emphasis will be particularly placed on multinational companies (MNC) to address the overall aims of this study. For example, studies by Warner and Peccei [4] show that such organisations' subsidiaries based in the United Kingdom allow local autonomy and blend in more to the local style in terms of practices. Such features have therefore, made it relevant to focus the attention of this particular research and even carry out studies (fieldwork) with similar firms as they currently depict the contemporary British way of conducting business. It is worth noting that interviews for this study were carried out with individuals from MNCs based in the East Midlands, United Kingdom.

There are a large number of MNCs operating in the United Kingdom, some of which are overseas-owned or United Kingdom-owned firms. However, members of society have always had a "love-hate" relationship with these MNCs and often criticise such organisations for being bureaucratic, inefficient and intrusive in its member's private lives [5]. In contrast, it is argued that the "downsides" of their activities are highlighted over the "upsides" like their contribution to society as a provider of employment, public services and private services. In addition to this role these organisations provide to the society, they are also involved in the system of government and the "birth, education, leisure and welfare of people throughout their lives" ([2], p. 75). It is, therefore, important to acknowledge the role that contemporary organisations play in the lives of individuals in terms of structuring and moulding it, within and outside the workplace.

As Morgan [6] suggests, complex political, economic and social organisations of a web of individual and social relationships offers its members an opportunity to partake in the wider society at local, national and even global levels. Valero-Silva [7] makes a reference to the central role and contribution that institutions like the prison, clinic and school have made to human existence.

"However, they also make constant demands on individuals for the latter to adjust to and comply with their internal procedures in the names, for instance, of efficiency and improved service. Only in the very remote and under-developed regions of the world do such institutions still remain exclusive and somehow detached from the daily lives of ordinary individuals and communities, or else their interaction is discontinued 
and/or sporadic." ([7], p. 1)

Littler [8] explains that organisational theory and practice should be viewed historically and contextually as it can only be understood as something in process, or else the search for general propositions and instant prescriptions will become detached from reality, which is often the case for "ahistorical" approaches. Furthermore it is necessary to recognise an understanding of organisations should be multi-dimensional rather than multi-layered especially when dealing with the complexities and levels of human behaviour in organisations. Thus many researchers have been critical of the approach to the human behaviour in organisations and have rejected the psychological component of mainstream theory that has often treated or regarded the people in organisations as “"psychologically determined' entities with abstractly and individually defined needs, for example the need to belong or for self-actualisation” ([5], p. 17).

In discussing and understanding how organisations have evolved in modern societies, particularly Britain, and the role that it may have on the constitution of organisational actors, it is important to consider that organisations often act as "people processors" through either their informal cultural and social practices or formal managerial measures to gain or mobilise approval. It is relevant to note that in studies involving organisations and their role and effect in wider social processes, there needs to be a critical consideration of existing realities and power relations. Thompson and McHugh [5] make mention of the perceived role of the organisation in "empowering" or "enabling" its employees to, for instance double their workload or go beyond the job description. They suggest that it only serves as a means of transforming the employees' workplace relations and that such a term does not imply any form of politics or intervention. It is argued that such terms like "empowerment" in organisational jargon moves away from its usual managerial usage and act merely as a term whose rhetoric is not matched by reality.

\section{Post Bureaucratic Organisations and Entrepreneurial Culture}

With a rapidly changing workplace, a phenomenon seen all over the world, due in part to new technologies, new market conditions, and new conceptions of employer-employee relations the issue of workplace control has become a concern [9]. That is, concern could be attributed to the "dominant" groups with how to obtain and exercise this control, and a concern from the "non-dominant" groups about new forms of domination, representational failure, and less satisfactory company performance ([9], p. 151). It is evident from the previous section that older forms of domination do exist; however, with the rise of new large-scale organisations, in tandem with participation and empowerment strategies and shifting work forces, new and more subtle forms of domination and control are now surfacing.

The notion of the post-bureaucratic organisation has been utilised by numerous researchers [10]-[12] to define a range of "contemporary" organisational forms that move away from the "traditional" bureaucratic organisation. It is explained in the case of new breed of post bureaucratic organisations, "rather than being structured in accordance with hierarchical principles, clearly bounded assignments and roles, and fixed career paths, the postbureaucratic organisation is characterised by fluidity, permeable and porous boundaries, and informal and organic structures” ([1], p. 639). Hence in such organisations, strategic planning processes may assume a more original and open-form, while control within organisations would have to be understated or softened [13] [14].

Iedema [15] explains that post-bureaucratic organisations rely on new forms of subjectivity and forms of identification constructed in the workplace. That is:

"For ordinary workers, the post-bureaucratic ethos asks no less than a 'frameshift' with respect to work, other, meaning, and self... Put in discourse terms, post-bureaucratic workers are asked to conceive of work and self as socially constructed, performatively maintained, and organisationally anchored.” ([15], p. 131)

Iedema [15] clarifies this definition by contrasting the post-bureaucratic organisation with the traditional bureaucratic "Fordist" organisation as follows:

"Whereas in Fordist and neo-Fordist organisations, employees fitted into clearly marked institutional hierarchies and were in charge of clearly circumscribed (proceduralised) and specialised tasks... postbureaucratic organisations tend to demand that they be multi-skilled, broad-banded, and linguistically articulate and assertive. Rather than management determining the sequence and manner in which tasks are to be carried out, employees are now encouraged to participate in the conceptualisation of tasks and of the work process as a whole. They negotiate their jobs as members of 'quality circles' and consultative com- 
mittees, as occurs in hospital settings where clinicians get together to protocolise and benchmark their practices.” ([15], p. 200)

Hence, it can be implied that the post-bureaucratic organisation structure enforces different and new forms of subjectivity and expectations for identification with the firm, and also the creation of new expertise. Thompson and Alvesson [16] point out that advocates of the post-bureaucratic notion believe that there has been a radical change from the traditional and outdated bureaucratic form to the current contemporary post-bureaucratic organisational form.

According to Deetz [9] these new forms of control are existent in so-called "knowledge-intensive" industries and also in the knowledge intensive parts of other firms. Thus by addressing and understanding such organisations and the units that make up majority of their rising segment of the workforce, especially in economically advanced societies, such forms of control in these firms can be exposed [17]. Clegg and Courpasson [18] argue that the process of rationalisation innate in past bureaucracies resulted in a diminution of liberty as officials were expected to develop into submissive subjects, enclosed in an "iron cage". Josserand [19] portrays an image of post-bureaucratic organisations as decentralised with cohesion gained through cross-cutting networks of numerous types, and in which the role of management changes to being a catalyst. However, Joserrand et al. [20] argue that as interesting as this new ideal-type may seem, it still depicts an abstract version of post-bureaucracy. It is added that the post-bureaucratic organisation is not devoid of the Weberian ideal-type but rather merges the old rationalisation techniques with new principles of networks and democracy. Hence:

"Post-bureaucracy does not mean the end of domination (Herrschaft) but it does mean that organizations and their management are caught in intrinsically ambiguous democratic mechanisms. Where legitimacy is premised on a political principle of democracy, it sits oddly within the frame of an older legitimacy of the power of office as (a legitimate) authority. In the former, domination is abhorred; in the latter it is inescapable, which changes dramatically the functioning of the line of command." ([20], pp. 55-56)

A central notion present in the literature is that management control has shifted from what is called technocratic control into diverse forms of normative control [21]; Foucauldian ideology emphasises how normative control, as a discourse, constitutes particular forms of subjectivity. Technocratic control denotes the form of control present in bureaucratic organisations to either have power over the process of the work such as work routines and scripts or the output of the work.

As mentioned earlier on in the discussion, Robertson and Swan's [22] study on knowledge-intensive firms, a type of organisation that is not entirely synonymous with post-bureaucratic organisation but mainly overlapping it, revealed that many firms depend on "cultural or professional forms of control". These forms of control are regarded to have dependence on an ideology of entrepreneurialism and enterprising culture [23]-[25] [bold added].

Although some researchers like Knights et al. [26] criticise the liberal use of the term knowledge-intensive firms and how it is used to denote a particular group of firms, it is clear that they do portray some "postbureaucratic" tendencies. Baron et al. [27] argue that there is little doubt that several firms particularly those operating in the high-tech sector utilise highly skilled experts and these firms organise in distinctive ways. Furthermore, Robertson and Swan [22] state that these firms represent a good example of contemporary forms of "people-dependent" organisations that holds close the ideology of "entrepreneurialism" as the pervasive structure of governance.

In the next section, we will demonstrate how the notion of entrepreneurialism have evolved in present-day organisations and has consequently been used as a tool or technique for controlling and rendering the employees as subjects.

\section{Post-Bureaucracy and Enterprise}

Although most contemporary organisations, particularly knowledge-intensive ones, may be governed through entrepreneurialism, they have been very few studies on how this organisational phenomenon may have evolved over time [21] [22]. As Du Gay (2004) explained, political discourses in many advanced liberal democracies, like the United Kingdom, have been inundated with mentions of "enterprise" for many years; mainly due to the dominance of "market" institutions in the constitution and reproduction of such societies. Peters [28] states that the idea of the "enterprise culture" emerged in the United Kingdom as a central theme in political thought under 
the Margaret Thatcher's administration. It is added that this notion signified a deep move away from the Keynesian welfare state to a deliberate attempt at cultural restructuring and engineering based upon the neo-liberal model of the entrepreneurial self; a moved symbolized by a move away from a "culture of dependency" to one of "self-reliance".

In distinguishing between the usual established usage and the organisational usage of the term enterprise, Du Gay [29] explains that:

“...contemporary usage is distinctive in traversing established definitions of 'enterprise' and 'entrepreneur' to signify a novel and vastly expanded meaning for the term. No longer does 'enterprise' refer simply to the creation of a independent business venture or to the characteristic habit of model entrepreneurs or (successful) persons in business for themselves, rather it refers to the ways in which economic, political, social and personal vitality is considered best achieved by the generalisation of a particular conception of the enterprise form to all forms of conduct-to the conduct of organisations previously seen as non-commercial..., to the conduct of government and its agencies and to the conduct of individuals.” ([29], pp. 38-39)

In this regard, the concept of enterprise therefore refers to both to the preferred enterprise form of organisation, and to a collection of features such as self-reliance, initiative and the capability to admit responsibility and accountability for one's self and one's actions [29]. Thus the term "enterprise as a rationality of neo-liberal government involves defining the conduct of organisational activity so as to produce autonomous, productive, self-regulating, entrepreneurial behaviour at both a collective and an individual level” ([30], p. 372). Dijksterhuis et al. [31] add that most large organisations, particularly knowledge-intensive firms, now exercise what is termed as "post-industrial management logic". This involves a practice whereby individuals are encouraged to reflect on their own behaviour and adjust their actions consequently with clear emphasis laid on self-control and self-organisation rather than organisational control. Thus Starbuck [32] adds that most knowledge-intensive firms would clearly derive their shared managerial schema from Post-industrial management logic.

Hence from the above discussion it is evident that concerning governance, the emphasis is largely placed on self-control and self-management in such firms. That is, a trait that is reminiscent of the entrepreneurial form; besides the work in these knowledge firms does demand autonomy and critical reflection [33]. However Doolin [30] argues that enterprise discourse is not the only form of discourse that is at play in contemporary societies and organisations. Moreover Fournier and Grey [34] suggest that in practice a number of discourses tend to be juxtaposed and do function together; additionally, there is not automatically a single source for a discourse or a total agreement over questions within it.

As Gordon [35] has revealed, enterprise as a principle of control or government is closely tied up with "ethics", a term Foucault defines as the "kind of relationship you ought to have with yourself, rapport also... which determines how the individual is supposed to constitute himself as a moral subject of his own actions" ([36], p. 352). This refers to the means by which individuals come to "understand and act upon themselves in relation to the true and the false, the permitted and the forbidden, the desirable and the undesirable" ([36], pp. 659-660). Also Gordon [37] points out that enterprise as a rationality of government encourages a conception of the individual person as an "entrepreneur of the self". That is:

"The idea of an individual human life as an enterprise of the self suggests that there is a sense in which no matter what hand circumstance may have dealt a person, he or she remains always continuously engaged (even if technically 'unemployed') in that one enterprise, and that it is 'part of the continuous business of living to make adequate provision for the preservation, reproduction and reconstruction of one's own human capital.” ([36], p. 660)

Thus Rose [25] defines the "enterprising self" as a calculating self, one that is calculative about itself and works upon itself in order to better itself. Du Gay [36] adds that modern organisational existence and eventual success is based on an engagement by the organisation of the "self-fulfilling impulses" of all of its members, regardless of their formal positions. They achieve this by allocating particular enterprising dispositions and capacities to employees by means of a number of mutually enhancing technologies and practices.

\section{Foucauldian Discourse Analysis}

Since this study aimed to use a Poststructuralist approach to address the main aims of the paper, a discourse analysis or discourse research was employed. However, it is important to note that discourse analysis is not in 
itself a "Poststructuralist method", or even a unitary approach [38]. For this paper, the analysis of discourses surrounding entrepreneurialism and "enterprise-culture" was done to enable us to understand the conditions behind the notion(s). It should also be noted that discourse analysis, with respect to a Poststructuralist analysis, has already received some attention in the field of policy analysis and management studies.

This body of discursive work can be usefully differentiated into that which concerns itself for the most part with the relatively formal communications of institutional discourse and that which is proximally concerned with the informal, "everyday" communication of "ordinary" discourse [39]. Therefore there are studies within Foucault's Poststructuralist analysis, which this paper has utilised, that trace the development of knowledge about enterprise discourse and their resulting power relations, and those that critically "deconstruct" prevailing discourses. This then allows us to say something about how power/knowledge operates in relation to enterprise culture in contemporary societies [40] [41].

\section{Conversations with Organisational Actors}

This section therefore draws on selection of interviews conducted with individuals working in Multi-National Corporations (three) in the United Kingdom. These organisations are business service firms and this industry represents a major growth area in the United Kingdom and therefore relevant to consider when addressing any issues concerning the contemporary British workplace.

The choice of the three workplaces ensures that the situation is thoroughly examined from various perspectives and Kraemer and Thiemann [42] explain that exploratory studies are not intended for generalisation to a large population but rather designed to increase knowledge in the field of study. According to Abramovsky et al. [43], business services have accounted for over fifty percent of job growth in the United Kingdom over the past two decades and this makes sampling from this sector critical to understanding the issue of entrepreneurialism and enterprise culture. That is, although this paper does not aim to be statistically representative, it is still necessary that the discourses gathered on a local level still give a typical reflection of the discourses on the national level.

Purposive sampling strategy was adopted because it enables the selection of information-rich cases over statistically representative ones that would result from probability sampling [44]. Because the aim of our research was to gather discourses among employees, which may be overlooked in most mainstream/managerialist workplace-based studies. Hence it was necessary for us to adopt purposive sampling instead of going for the usual cases, a cross-section or a balanced choice, we as researchers would be able to focus on cases which exhibit broad range and possibly even focus on extreme cases to illuminate the topic at hand [45].

The reason we conducted semi-structured interviews was to provide qualitative information which would facilitate a deeper understanding of the individuals' representations and experiences regarding "enterprising" roles and the notion of entrepreneurialism in their respective workplaces. It is important to restate that the opinions that these organisational actors provided were not sought to support or oppose a particular line of thoughts on entrepreneurialism, but rather to show the richness of the research topic and its originality through the provision of a platform for these diverging views to be aired and debated. That is, the aim was to gather discourses among people in the workplace, which may be overlooked or neglected in most mainstream workplace-based studies, and to contrast them with political and managerial "official" accounts.

\section{The Discussion-The Enterprising Self}

Du Gay [23] mentions that the restructuring of organisations in contemporary societies at the level of commercial entities working in a competitive environment necessitates the production of enterprising behaviour by organisations and organisational actors. In the case of the latter, Foucault's conception of "disciplinary power" and "social technologies of control" have been very vital in revealing and understanding new forms of domination on individuals that occur in a number of different organisations. Knights and Murray [46] state that discourses such as that of enterprise act upon the subjectivity of individuals, constituting the sense of what it is to be enterprising, and restricting certain ways of thinking and acting, while revealing others.

Doolin [30] explains that most discourses employed in certain organisations have the ability to constitute organisational participants as subjects who gained their organisational identities, reality, and sense of meanings through partaking in such discourses and related practices. Moreover, Peters in his discussion on how promotion of an enterprise culture has become a style of government characteristic of both neoliberalism and Third Way 
politics states that:

"A genealogy of the entrepreneurial self reveals that it is the relationship, promoted by neoliberalism that one establishes to oneself through forms of personal investment... insurance that becomes the central ethical component of a new individualised and privatised consumer welfare economy. In this novel form of governance, responsibilised individuals are called upon to apply certain management, economic, and actuarial techniques to themselves as subjects of a newly privatised welfare regime.” ([28], p. 60)

As Doolin [30] notes, discourses and particularly those relating to enterprise, offer means by which individuals come to understand themselves as subjects and makes reference to Foucault's notion of "governmentality"; he suggests that employee/worker autonomy can be understood in terms of govermentality. Governmentality, which refers to Foucault's work on macrophysical practices of government, was based on the foundations of his previous studies on microphysics of power and discipline. He adds that:

"It has at its objective the normalisation of the self-regulating subject, and encompassed governmental programmes of not only the state, but also private- and public-sector institutions and individual conduct. In this sense, government is not the overt extension of control from some centre of power, but rather the conduct of conduct-influencing the action of others by working on their autonomous subjectivity... Governmentality operates through various heterogeneous sociotechnologies of controlling, organising and ordering related to the construction of incalculable spaces and the shaping of the self." ([30], p. 375)

Thus such technologies of government express and symbolise that which is "right" and "suitable" conduct for individuals and collectives. As Doolin [30] explains, their actions grant individuals a particular subjectivity that shapes and guides them in their daily regimes and decisions. Consequently individuals end up entwined in pursuing social, political and economic objectives which are stimulated by individuals who, as subjects, come to identify with and normalise their actions in terms of standards inherent in governmental institutions and programmes.

Fleming and Spicer [47] cite the usefulness of applying Foucault's ideology to labour process theory and suggest that by rejecting essentialist views of human nature, subjectivity is seen as a result of disciplinary mechanisms, techniques of surveillance and power/knowledge approaches. Furthermore, by understanding the relationship between subjectivity and power, most researchers have aimed to understand the way that workers inscribe themselves in power relations and become "the principle of their own subjection" ([48], p. 203). Most studies of contemporary organisations based on power and subjectivity have looked critically at the corporate culture, and recently entrepreneurial culture, and the effects on the "selves" of its workers. Mutch [49] also mentions that the concept of culture has been mostly developed at the level of organisations and suggests a need to evaluate how these concepts overlap with the conceptions of power.

Hence, numerous amounts of critical research studies have been aimed at identifying how culture building and related technologies are basically systems of management control that intend to capture the identities of employees; that is, understanding how the individual is transformed into a productive and less recalcitrant employee, just the way the organisation expects [47]. Peters [28] refers to the work of anthropologist Mary Douglas who commences her discussion of the person in enterprise culture by arguing that enterprise culture is "justified by the claim that it frees persons [driven by self-interested motives] from constraints" enforced by bureaucratic regulation which "inhibit the pursuit of freely-chosen objectives, and so infringes the essential liberties of the person” ([50], p. 41).

"For Douglas, the self and the concept of person is locked into ideology, and the 'recognising the ideological structure of the self is the right starting-point for an investigation'. She indicates the way in which the self and the person have become separated in Western discourse over the last three hundred years, where the private self is bracketed from inquiry so as to protect the freedom of persons from ideological coercion and the category of the person "has been filled by the need to meet the forensic requirement of a law-abiding society and an effective, rational judicial system'.” ([28], pp. 66-67)

Rose [51] analyses types of political reason that try to produce an enterprise culture by assigning a certain political value to the self, as an "enterprising self", and also makes reference to Foucault's work. That is, Foucault's work is "productive for 'linking practices bearing on the self to forms of power' where power is not considered repressive, dominating and negating the capacity of individuals, but 'as the creation, shaping, and utili- 
sation of human beings as subjects’...such that power works through subjectivity” ([28], p. 67).

Furthermore [51] suggests that to understand the relationship or the link between the self and power through a Foucauldian perspective, one has to document and evaluate the means by which human beings have been created as subjects through different law-making strategies and forms of regulation. Utilising a Foucauldian view on the issue of governance and control thus is not focused on liberalism as a political philosophy or ideology but rather "reconfigures it as a form of governmentality with an emphasis on the question of how power is exercised"; consequently... "it makes central the notion of the self-limiting state which, in contrast to the administrative (or 'police') state, brings together in productive ways questions of ethics and technique, through the responsibilisation of moral agents and the active reconstruction of the relation between government and self- government” ([28], p. 67).

From the discussion in this section, it is evident that the identification and acceptance that individuals do indeed bring their own meanings and personal work orientations to the workplace may now be seen as challenging the traditionally-held assumption that organisational members are rigid entities with given "personalities" which changes little over a lifetime [52]. Such a shift towards a more relational view of organisational members and their identities was explained by Watson as being initiated by researchers in the poststructuralist realm questioning the prior assumption that each person has an unchanging "sovereign" or "essential" self. Employee subjectivity is consequently viewed as a result of disciplinary mechanisms, techniques of surveillance and powerknowledge strategies [48] [53]. Watson explains that although researchers like Alvesson and Willmott [54]:

“...concentrate on the efforts made by employing organisations to accomplish organisational control 'through the self-positioning of employees within managerially inspired discourses', they acknowledge that this can never be fully accomplished because such attempts are balanced by individuals with other elements of life history forged by a capacity to accomplish life projects out of various sources of influence and inspiration." ([52], p. 125)

Furthermore, it is possible to suggest that workers in knowledge-intensive firms were individuals one would expect to have taken in to some degree the discourses of identity that are dominant currently with their industry and, particularly, the notion of the "enterprising self" [55]. However, Storey et al. summarised that workers diversely "incorporate, modify, or reject notions of enterprise in their reflexively organised narrative of self" and argued against perceived dominance of the notion of the enterprising self [23]. In addition, Bolton and Houlihan [56] imply, in their study of customer service in call-centres, that the power of the discourses of enterprise has been over-estimated.

\section{Implications of the Enterprise Culture on the Employee}

Based on the above discussion, the complexities and ambiguities that are inherent in the debate, particularly concerning the organisational intricacies concerning the enterprise culture and the actual practices in the workplace, become apparent. Furthermore, following the interviews, it also became apparent that the organisations being studied have utilised numerous policies under the guise of entrepreneurialism as part of their disciplinary technologies through which they assert authority over the relation between knowledge, the work and the worker. For instance, by promoting the enterprise culture and making the employees feel that they are autonomous, self-regulating individuals, the employees, at times, convince themselves that management is implementing such policies for benefit of the workforce and the organisation as a whole.

From the interviews, it was clear at times that some of the employees believed or accepted management's decision to promote this enterprising spirit based on the reasons that were stated by the management. Hence these workers become governable due to their agreement of knowledge that is offered by management pertaining to entrepreneurialism. In the case of the office-based work environment and knowledge-intensive firms the reason that management gave for introducing an enterprise culture or ideology was to facilitate a shift from a "culture of dependency" to one of "self-reliance".

Thus when employees have accepted the truth claims made by the organisation about enterprise culture, and the precise collections of knowledge making them possible, they act in a way as to maintain these "truths" even in instances where the underlying concepts of these notions may not explicitly permeate. Consequently the employees partake in the production of power that affects them and through their practices and exploits substantiate and reinforce it; its perceived authority and its rationality [57]. 
However, it is necessary to point out that management or supervisors are not always principals in this process. As we identified in the interviews, the organisation's techniques on enforcing an enterprising workforce have a tendency to produce workers whose actions are consistent with its demands for conformity and increased organisational efficiency. Nonetheless, it is not just that the organisation controls the workers until they all accept or comply with what management requires of them. The workforce can utilise mechanisms and techniques produced by management different ways, "ranging from compliance through proper means to compliance through unofficial or proscribed means, to subversion or outright resistance” ([57], p. 126).

\section{Conclusions}

This paper has shown the importance of the large-scale organisations, particularly knowledge-intensive firms, in contemporary societies and their role in producing and affecting the identities of individuals that work in them. The changing nature of the wider societal culture has also been attributed to particular shifts in the way organisations now perform their activities. Furthermore, the recent rise of the "enterprise-culture" has been deemed significant in the way organisations and their relevant actors behave and carry out all aspects of the roles in society. At the forefront of this discussion, there has also been the role of the individual in all this shifting and constant debate about how individual working lives are shaped by their respective work organisations; this force or control is seen to be imposed by the latter to ensure that the organisational actors "adjust to and comply with their internal procedures in the names, for instance, of efficiency and improved service” ([7], p. 1).

In addition as discussed in methodology section of this paper, by adopting a Foucauldian approach, many aspects of an individual's existence including issues of self-empowerment and self-reliance can be "problematised" in contemporary society and examined while acknowledging the importance of work institutions and the roles they play in the wider society. Furthermore it is already clear in this paper that there are emerging issues regarding power that have contributed to shaping the view of society towards the "entrepreneurial" culture; for instance, how views and opinions of certain "experts" and institutions have remained dominant over time in the debate about how the individual is viewed and dealt with in society and particularly in the workplace.

In sum, the discussions above suggest that there is a need for a thorough and rigorous debate about what is meant by "entrepreneurialism" and "enterprise culture". Any attempt to redefine the terms, should note that the notions of entrepreneurialism and enterprise culture is a dynamic endeavour that is influenced by numerous institutions, actors, disciplines and interests and therefore, deserves better explanations as it cannot be studied without addressing the wider social processes that exist as a result of the "problematisation" of these key notions.

\section{References}

[1] Styhre, A. (2008) Management Control in Bureaucratic and Postbureaucratic Organizations: A Lacanian Perspective. Group and Organization Management, 33, 635-656.

[2] Watson, T.J. (2003) Sociology, Work and Industry. 4th Edition, Routledge, London.

[3] Strati, A. (2000) Theory and Method in Organization Studies. Paradigms and Choices. Newbury Park, Sage.

[4] Warner, M. and Peccei, R. (1997) Worker-Participation and Multinational Companies. Management International Review, 17, 93-98.

[5] Thompson, P. and McHugh, D. (2002) Work Organisations. 3rd Edition, Basingstoke, Palgrave.

[6] Morgan, G. (1986) Images of Organizations. Newbury Park, Sage.

[7] Valero-Silva, N. (2007) The Study of Institutions in the Understanding of Contemporary Social Processes. Proceedings of the 51st Annual Meeting of the ISSS, Tokyo, 6 August 2007, 1-7.

[8] Littler, C.R. (1980) Internal Contracts and Transition to Modern Work Systems. In: Dunkerley, D. and Salaman, G., Eds., The International Yearbook of Organisaton Studies, Routeledge/ Kegan Paul, London.

[9] Deetz, S. (1998) Discursive Formations, Strategised, Subordination and Self-Surveillance. In: McKinlay, A. and Starkey, K., Eds., Foucault, Management and Organisation Theory, Sage Publications Ltd., London, 151-172.

[10] Garsten, C. and Grey, C. (1997) How to Become Oneself: Discourses of Subjectivity in Post-Bureaucratic Organizations. Organization, 2, 211-228.

[11] Hodgson, D.E. (2000) Discourse, Discipline and the Subject: A Foucauldian Analysis of the UK Financial Services Industry. Ashgate, Aldershot. 
[12] Maravelias, C. (2003) Post-Bureaucracy-Control through Professional Freedom. Journal of Organizational Change Management, 16, 547-566. http://dx.doi.org/10.1108/09534810310494937

[13] Mintzberg, H. (1993) The Pitfalls of Strategic Planning. California Management Review, 36, 32-47. http://dx.doi.org/10.2307/41165733

[14] Marx, T. (1991) Removing the Obstacles to Effective Strategic Planning. Long Range Planning, 24, 21-28. http://dx.doi.org/10.1016/0024-6301(91)90003-7

[15] Iedema, R. (2003) Discourses of Post-Bureaucratic Organization. John Benjamins, Amsterdam/Philadelphia. http://dx.doi.org/10.1075/ddcs.5

[16] Thompson, P. and Alvesson, M. (2005) Bureaucracy at Work: Misunderstandings and Mixed Blessings. In: Du Gay, P., Ed., The Values of Bureaucracy, Oxford University Press, Oxford, 89-113.

[17] Drucker, P. (1993) Post Capitalist Society. Harper Business, New York.

[18] Clegg, S. and Courpasson, D. (2004) Political Hybrids: Tocquevillean Views on Project Organizations. Journal of Management Studies, 41, 525-547. http://dx.doi.org/10.1111/j.1467-6486.2004.00443.x

[19] Josserand, E. (2004) The Network Organization, the Experience of Leading French Multinationals. Edward Elgar, Cheltenham.

[20] Josserand, E., Teo, S. and Clegg, S. (2006) From Bureaucratic to Post-Bureaucratic: The Difficulties of Transition. Journal of Organisational Change Management, 19, 54-64. http://dx.doi.org/10.1108/09534810610643686

[21] Alvesson, M. (2004) Knowledge Work and Knowledge-intensive Firms. Oxford University Press, Oxford.

[22] Robertson, M. and Swan, J. (2004) Going Public: The Emergence and Effects of Soft Bureaucracy within a Knowledge-Intensive Firm. Organisation, 11, 123-148. http://dx.doi.org/10.1177/1350508404039661

[23] Du Gay, P. (1996) Consumption and Identity at Work. Sage, London.

[24] McCarthy, J.F. (2008) Short Stories at Work: Storytelling as an Indicator of Organizational Commitment. Group and Organization Management, 33, 163-193. http://dx.doi.org/10.1177/1059601108314582

[25] Rose, N. (1999) Power of Freedom: Reframing Political Thought. Cambridge University Press, Cambridge.

[26] Knights, D., Murray, F. and Willmott, H. (1993) Networking as Knowledge Work: A Study of Strategic Interorganisational Development in the Financial Services Industry. Journal of Management Studies, 30, 975-995. http://dx.doi.org/10.1111/j.1467-6486.1993.tb00475.x

[27] Baron, J., Hannan, M. and Burton, D. (2001) Labour Pains: Change in Organisational Models and Employee Turnover in Young High-Tech Firms. American Journal of Sociology, 106, 960-1012. http://dx.doi.org/10.1086/320296

[28] Peters, M. (2001) Education, Enterprise Culture and the Entrepreneurial Self: A Foucauldian Perspective. Journal of Educational Enquiry, 2, 58-71.

[29] Du Gay, P. (2004) Against "Enterprise” (But Not against "Enterprise”, for That Would Make No Sense). Organisation, 11, 37-57. http://dx.doi.org/10.1177/1350508404039777

[30] Doolin, B. (2002) Enterprise Discourse, Professional Identity and the Organisational Control of Hospital Clinicians. Organisation Studies, 23, 369-390. http://dx.doi.org/10.1177/0170840602233003

[31] Dijksterhuis, M., Van den Bosch, F. and Volberda, H. (1999) Where Do New Organizational Forms Come from? Management Logics as a Source of Co-Evolution. Organization Science, 10, 569-582. http://dx.doi.org/10.1287/orsc.10.5.569

[32] Starbuck, W. (1992) Learning by Knowledge-Intensive Firms. Journal of Management Studies, 29, 713-740. http://dx.doi.org/10.1111/j.1467-6486.1992.tb00686.x

[33] Kelley, R. (1990) The Gold Collar Worker: Harnessing the Brainpower of the New Workforce. Addison-Wesley, Reading.

[34] Fournier, V. and Grey, C. (1999) Too Much, Too Little and Too Often: A Critique of du Gay’s Analysis of Enterprise. Organisation, 6, 107-128. http://dx.doi.org/10.1177/135050849961005

[35] Gordon, C. (1991) Governmental Rationality: An Introduction. In: Burchell, G., Gordon, C. and Miller, P., Eds., The Foucault Effect, Harvester Wheatsheaf, Brighton, 1-51.

[36] Du Gay, P. (1994) Making up Managers: Bureaucracy, Enterprise and the Liberal Art of Separation. The British Journal of Sociology, 45, 655-674. http://dx.doi.org/10.2307/591888

[37] Gordon, C. (1987) The Soul of the Citizen: Max Weber and Michel Foucault on Rationality and Government. In: Whimster, S. and Lask, S., Eds., Max Weber: Rationality and Modernity, Allen \& Unwin, London, 293-316.

[38] Wetherell, M., Taylor, S. and Yates, S. (2001) Discourse Theory and Practice: A Reader. Sage, London.

[39] Martin, A. and Stenner, P. (2004) Talking about Drug Use: What Are We (And Our Participants) Doing in Qualitative 
Research? International Journal of Drug Policy, 15, 395-405. http://dx.doi.org/10.1016/j.drugpo.2004.05.005

[40] Holguin, B.A. (2007) Understanding the Cannabis Reclassification in the United Kingdom 2002-04. Doctor of Management Thesis, Hull.

[41] Campbell, D. and Graham, M. (1988) Drugs and Alcohol in the Workplace: A Guide for Managers. Facts on File Publications, New York.

[42] Kraemer, H.C. and Thiemann, S. (1987) How Many Subjects? Statistical Power Analysis in Research. Sage, Newbury Park.

[43] Abramovsky, L., Griffith, R. and Sako, M. (2004) Offshoring Business Services and Its Impact on the UK Economy. Advanced Institute of Management Research, 1-36. http://dx.doi.org/10.2139/ssrn.1463419

[44] Patton, M.Q. (2002) Qualitative Research and Evaluation Methods. 3rd Edition, Sage, Thousand Oaks.

[45] Dane, F.C. (1990) Research Methods. Brooks/Cole Publishing Company, Pacific Grove.

[46] Knights, D. and Murray, F. (1994) Managers Divided: Organisation Politics and Information Technology Management. John Wiley, Chichester.

[47] Fleming, P. and Spicer, A. (2003) Working at a Cynical Distance: Implications for Power, Subjectivity and Resistance. Organization, 10, 157-179. http://dx.doi.org/10.1177/1350508403010001376

[48] Foucault, M. (1977) Discipline and Punish: The Birth of the Prison. Allen Lane/Penguin Press, London.

[49] Mutch, A. (2008) Power Culture and Information. In: Mutch, A., Ed., Managing Information and Knowledge in Organizations: A Literary Approach, Routledge, Abingdon, 197-213. http://dx.doi.org/10.4324/9780203933176.ch9

[50] Douglas, M. (1992) The Person in the Enterprise Culture. In: Heap, S. and Ross, A., Eds., Understanding the Enterprise Culture: Themes in the Work of Mary Douglas, Edinburgh University Press, Edinburgh, 41-62.

[51] Rose, N. (1990) Governing the Soul: The Shaping of the Private Self. Routledge, London.

[52] Watson, T.J. (2008) Managing Identity: Identity Work, Personal Predicaments and Structural Circumstances. Organisation, 15, 121-143. http://dx.doi.org/10.1177/1350508407084488

[53] Knights, D. and Willmott, H. (1989) Power and Subjectivity at Work: From Degradation to Subjugation at Work. Sociology, 23, 535-558. http://dx.doi.org/10.1177/0038038589023004003

[54] Alvesson, M. and Willmott, H. (2002). Identity Regulation as Organisational Control: Producing the Appropriate Individual. Journal of Management Studies, 39, 619-644. http://dx.doi.org/10.1111/1467-6486.00305

[55] Storey, J., Salaman, G. and Platman, K. (2005) Living with Enterprise in an Enterprise Economy: Freelance and Contract Workers in the Media. Human Relations, 58, 1033-1054. http://dx.doi.org/10.1177/0018726705058502

[56] Bolton, S. and Houlihan, M. (2002) Tensions and Variations in Call Centre Management Strategies. Human Resource Management Journal, 12, 67-85. http://dx.doi.org/10.1111/j.1748-8583.2002.tb00078.x

[57] Winiecki, D. and Wigman, B. (2007) Making and Maintaining the Subject in Call Centre Work. New Technology, Work and Employment, 22, 118-131. http://dx.doi.org/10.1111/j.1468-005X.2007.00188.x 